CZASOPISMO INŻYNIERII LĄDOWEJ, ŚRODOWISKA I ARCHITEKTURY JOURNAL OF CIVIL ENGINEERING, ENVIRONMENT AND ARCHITECTURE JCEEA, t. XXXIII, z. 63 (2/I/16), kwiecień-czerwiec 2016, s. 241-252

Andżelika PIETRZYK ${ }^{1}$

Dorota PAPCIAK ${ }^{2}$

\title{
MATERIA ORGANICZNA W WODACH NATURALNYCH - FORMY WYSTĘPOWANIA I METODY OZNACZANIA
}

\begin{abstract}
Ilość materii organicznej jest ważnym parametrem decydującym o stopniu zanieczyszczenia wód naturalnych. Jedynym dobrze zdefiniowanym wskaźnikiem określającym sumę wszystkich organicznych zanieczyszczeń jest ogólny węgiel organiczny (OWO). W artykule omówione zostały metody wykorzystywane do pomiaru OWO oraz formy występowania materii organicznej w różnych typach wód. Zawartość ogólnego węgla organicznego w wodach naturalnych jest zróżnicowana i zależy od następujących czynników: typu i wielkości badanego zbiornika wodnego, położenia geograficznego, temperatury, zasolenia, wartości pH, aktywności mikrobiologicznej oraz charakteru zlewni. Wzrost zawartości ogólnego węgla organicznego w wodach, które ujmowane są w celu zaopatrywania ludności w wodę przeznaczoną do picia wpływa na znaczne zwiększenie kosztów jej uzdatniania. Obecność substancji organicznych, a przede wszystkim substancji humusowych przyczynia się do pogorszenia właściwości organoleptycznych wody m.in. są one odpowiedzialne za występowanie specyficznego smaku i zapachu, a także za ponadnormatywną barwę.
\end{abstract}

Słowa kluczowe: ogólny węgiel organiczny (OWO), zawieszony węgiel organiczny (ZWO), rozpuszczony węgiel organiczny (RWO), biodegradowalny węgiel organiczny (BWO)

\section{Wprowadzenie}

Zawartość materii organicznej jest jednym z parametrów określających stopień zanieczyszczenia środowiska. W celu oszacowania jej ilości powszechnie wykorzystywane są wskaźnikowe oznaczenia grupowe, które reprezentują sumaryczną zawartość poszczególnych związków chemicznych. W analizie wody można posłużyć się różnymi metodami pośrednimi, do których należy zaliczyć

\footnotetext{
${ }^{1}$ Autor do korespondencji/corresponding author: Andżelika Pietrzyk, Politechnika Rzeszowska, Zakład Oczyszczania i Ochrony Wód, Al. Powstańców Warszawy 6, 35-959 Rzeszów, tel. 691259551, d332@stud.prz.edu.pl

${ }^{2}$ Dorota Papciak, Zakład Oczyszczania i Ochrony Wód, Al. Powstańców Warszawy 6, 35-959 Rzeszów,dpapciak@prz.edu.pl
} 
m.in.: biochemiczne zapotrzebowanie na tlen (BZT), chemiczne zapotrzebowanie na tlen (ChZT), absorbancję UV oraz straty przy prażeniu suchej pozostałości. Najczęściej stosuje się metodę bezpośrednią, polegającą na utlenianiu związków węgla do dwutlenku węgla, a następnie jego ilościowe oznaczenie za pomocą różnych detektorów [1 - 3]. Spośród wszystkich wymienionych metod jedynie pomiar ogólnego węgla organicznego (OWO) daje pełną informację o sumie wszystkich związków organicznych występujących w analizowanej próbce [4]. Pojęcie ogólnego węgla organicznego definiowane jest jako całkowita zawartość węgla w rozpuszczonej i nierozpuszczonej materii organicznej. Parametr ten nie dostarcza jednak szczegółowych informacji o rodzaju poszczególnych związków organicznych [3,5].

Dokładne oszacowanie zawartości związków organicznych w wodach naturalnych jest niezwykle ważnym zagadnieniem, któremu poświęca się coraz więcej uwagi. Obecnie ogólny węgiel organiczny jest wskaźnikiem normowanym przez polskie prawodawstwo. Graniczne stężenia OWO określone zostały dla wszystkich trzech kategorii wód powierzchniowych (A1, A2, A3), tj. 5 mg/l wody wymagające prostego uzdatniania fizycznego, $10 \mathrm{mg} / \mathrm{l}$ - wody wymagające typowego uzdatniania fizycznego i chemicznego oraz $15 \mathrm{mg} / \mathrm{l}$ - wody wymagające wysokosprawnego uzdatniania fizycznego i chemicznego [6]. Najwyższa dopuszczalna zawartość ogólnego węgla organicznego w ściekach, które odprowadzane są do wód lub do ziemi może wynosić natomiast $30 \mathrm{mg} / \mathrm{l}$ [7]. Z kolei w wodzie przeznaczonej do spożycia przez ludzi dopuszczalna zawartość OWO określona została terminem: „bez nieprawidłowych zmian”[8]. O wystąpieniu nieprawidłowych zmian można mówić wówczas, gdy różnica pomiędzy największą i najmniejszą wartością OWO w skali roku jest wyższa od $40 \%$ wartości minimalnej [9].

\section{Materia organiczna $w$ wodach naturalnych}

Materia organiczna występująca w wodach może być zarówno pochodzenia naturalnego jak również antropogenicznego. Do naturalnie występujących substancji organicznych możemy zaliczyć przede wszystkim związki humusowe (tj. kwasy humusowe, kwasy fulwowe $\mathrm{i}$ huminy), produkty przemiany materii mikroorganizmów, a także związki pochodzące $\mathrm{z}$ rozkładu martwych roślin i zwierząt $[2,10]$. Natomiast wśród zanieczyszczeń antropogenicznych wymienić należy m.in. fenole, substancje powierzchniowo czynne, wielopierścieniowe węglowodory aromatyczne (WWA), chlorowane związki organiczne (ChZO), pestycydy oraz związki ropopochodne. Głównym źródłem zanieczyszczeń syntetycznych są odcieki ze składowisk odpadów, ścieki, nawozy oraz środki ochrony roślin [5, 10 - 12]. Zawartość syntetycznych oraz naturalnych związków organicznych $\mathrm{w}$ wodzie zależna jest przede wszystkim od typu wód oraz od stopnia ich zanieczyszczenia. Zazwyczaj wody podziemne zawierają śladowe ilości substancji organicznych w przeciwieństwie do wód powierzchniowych, 
które mogą charakteryzować się ich znaczą zawartością (szczególnie wody silnie zanieczyszczone) [2]. Działalność człowieka oraz naturalnie występujące w środowisku procesy przyczyniają się do zwiększenia zawartości związków organicznych zarówno w wodach, glebach jak również osadach dennych [13].

Naturalna materia organiczna (NOM) jest ogólnym terminem określającym wszystkie związki organiczne występujące w wodach naturalnych [14]. Węgiel organiczny może występować w dwóch podstawowych formach - rozpuszczonej (RWO) i zawieszonej (ZWO), a łączna suma tych obu parametrów stanowi całkowitą zawartość OWO [13]. Rozpuszczony węgiel organiczny definiowany jest jako sumaryczna zawartość węgla organicznego pochodzącego ze związków, które przechodzą przez filtr membranowy o średnicy porów $0,45 \mu \mathrm{m}$. Do tej grupy można zaliczyć m.in. ultra małe bakterie (o wielkości mniejszej niż $0,2 \mu \mathrm{m}$ ), wirusy oraz kwasy organiczne wchodzące w skład związków humusowych. Inne substancje określane mianem RWO to m.in. aminokwasy, cukry proste, hydroksykwasy oraz kwasy tłuszczowe. Z kolei zawieszony węgiel organiczny (ZWO) to głównie zooplankton, glony, pierwotniaki, zawiesina bakterii i ich pojedyncze komórki, a także część substancji organicznych wyługowanych z gleb i roślin [14]. W wodach słodkich około 90\% całkowitej materii organicznej występuje w postaci frakcji rozpuszczonej [15].

Zawartość ogólnego węgla organicznego w wodach naturalnych jest zróżnicowana i zależy od następujących czynników: typu wody, wielkości badanego zbiornika wodnego, położenia geograficznego, temperatury, zasolenia, wartości $\mathrm{pH}$, aktywności mikrobiologicznej oraz charakteru zlewni $[5,16]$. W tabeli 1 przedstawiono zakresy stężeń OWO, stwierdzonych w różnych typach wód.

Tabela 1. Wartości węgla organicznego występujące w różnych typach wód

Table 1. The organic carbon content in the different types of waters

\begin{tabular}{|l|c|c|}
\hline \multicolumn{1}{|c|}{ Typ wody } & OWO [mg/l] & Referencje \\
\hline Rzeki & $0,8-78$ & {$[17-20]$} \\
\hline Jeziora & $8,3-24,1$ & {$[21]$} \\
\hline Wody gruntowe & $22,6-101,7$ & {$[12,22]$} \\
\hline Wody podziemne & $0,3-36$ & {$[1,15,23,24]$} \\
\hline Wody deszczowe & $0,3-44,1^{*}$ & {$[25,26]$} \\
\hline Wody morskie & $2,38-8,24^{*}$ & {$[27]$} \\
\hline
\end{tabular}

*Wartość rozpuszczonego węgla organicznego (RWO)

Zawartość rozpuszczonego węgla organicznego w wodzie może ulegać wyraźnym zmianom w zależności od strefy klimatycznej. Najmniejsze wartości występują w terenach górskich, arktycznych oraz suchych (RWO = $2-3 \mathrm{mg} / \mathrm{l})$ co uwarunkowane jest małą produktywnością roślin. Z kolei $\mathrm{w}$ regionach charakteryzujących się wysokimi temperaturami, pomimo dużej produkcji pierwotnej stężenie rozpuszczonego węgla organicznego kształtuje się na poziomie 
$6-7 \mathrm{mg} / \mathrm{l}$. Jest to wynikiem szybkiej mineralizacji związków organicznych w tych strefach klimatycznych. Najwyższe wartości tego parametru występują natomiast w klimacie tajgi, gdzie stężenia RWO wynoszą średnio $10 \mathrm{mg} / \mathrm{l}$ [28].

Światowe raporty dostarczają informacji, iż w ciągu ostatnich kilku dekad ilość materii organicznej $\mathrm{w}$ wodach powierzchniowych nieustannie wzrasta. W ostatnich latach zaobserwowano wzrost stężenia ogólnego węgla organicznego w ciekach wodnych na terenie Europy (m.in. w Wielkiej Brytanii i Norwegii) oraz w Ameryce Północnej [16, 19, 29]. Zwiększające się stężenia substancji organicznych mogą mieć znaczący wpływ na florę i faunę wód powierzchniowych, jakość wody przeznaczonej do picia oraz sposób jej uzdatniania [29]. Przyczyny wzrostu ilości materii organicznej nie są jeszcze dostatecznie poznane lecz uważa się, że mogą one zależeć od takich czynników jak: zmiany klimatyczne, intensywność nasłonecznienia, wielkość opadów, wilgotność gleby, wzrost stężenia $\mathrm{CO}_{2} \mathrm{w}$ atmosferze oraz depozycja atmosferyczna [19].

$\mathrm{W}$ wodach jeziornych również dominuje rozpuszczona forma węgla organicznego (zawieszony węgiel organiczny stanowi zaledwie ok. 10\% rozpuszczonego węgla organicznego) [21]. W tym przypadku wartość RWO będzie zależała głównie od trofii jeziora. Wielkość tego parametru może oscylować w granicach od $1 \mathrm{mg} / \mathrm{l} \mathrm{w}$ warunkach oligotroficznych (niska zawartość substancji odżywczych rozpuszczonych w wodzie) do nawet $50 \mathrm{mg} / \mathrm{l} \mathrm{w}$ warunkach dystroficznych (niedobór substancji odżywczych rozpuszczonych w wodzie). Największe stężenia OWO są odnotowywane w jeziorach charakteryzujących się znaczną ilością substancji humusowych, niedoborem tlenu i substancji pokarmowych, ubogą fauną i florą, a także kwaśnym odczynem wody [28].

W przypadku wód podziemnych zawartość substancji organicznych również jest zróżnicowana, a jej średnie wartości oscylują od 0,2 do $15 \mathrm{mg} / \mathrm{l}$. Mniejsze stężenia materii organicznej w wodach podziemnych można tłumaczyć faktem, iż wraz z upływem czasu, stężenie OWO ulega znacznemu obniżeniu. Zjawisko to jest spowodowane procesem mineralizacji związków organicznych tj. chemiczną i biologiczną degradacją do dwutlenku węgla, który może przebiegać zarówno w procesach tlenowych jak i beztlenowych. Większe stężenia OWO najczęściej są obserwowane w wodach, które znajdują się w bliskim sąsiedztwie złóż węgli brunatnych lub torfowisk [28].

Do wzbogacenia wód powierzchniowych i podziemnych w substancje organiczne przyczyniają się ekosystemy bagienne, charakteryzujące się znaczną zawartością materii organicznej. Ma to miejsce szczególnie podczas intensywnych opadów oraz w wyniku zwiększonego spływu wody z obszaru zlewni do rzek [12]. Według badań Kiryluk [22] stężenia OWO w wodach powierzchniowych badanych na terenach pobagiennych były zróżnicowane, a uzyskane wartości mieściły się w zakresie od 22,99 do $86,31 \mathrm{mg} / \mathrm{l}$. W przypadku wód gruntowych (zaskórnych) odnotowano stężenia, które oscylowały w granicach od 22,55 do 101,66 mg/l. Przyczyną wyższych wartości OWO w wodach gruntowych może być bezpośrednie przenikanie substancji organicznych z mineralizu- 
jącej się masy torfowej. Sposób użytkowania ekosystemów pobagiennych również miał wpływ na zawartość substancji organicznej w wodzie gruntowej. Największe stężenia odnotowano $\mathrm{w}$ wodach pobranych $\mathrm{z}$ intensywnie użytkowanych pastwisk [22]. Zawartość materii organicznej zależna jest przede wszystkim od właściwości fizycznych i chemicznych gleb. Gleby bogate w węgiel są głównym źródłem RWO w środowisku wodnym [29].

Wody deszczowe w swoim składzie również zawierają pewne ilości substancji organicznych. Rozpuszczony węgiel organiczny jest jednym z głównych składników morskich i kontynentalnych deszczy, którego średnie stężenia wynoszą odpowiednio 0,28 i $1,93 \mathrm{mg} / 1$ [25]. Z danych literaturowych wynika, że na terenach uprzemysłowionych stężenia RWO mogą osiągać znaczne wyższe wartości. W badaniach przeprowadzonych $\mathrm{w}$ północnych Chinach średnie roczne stężenie RWO w wodach opadowych wahały się od 0,3 do $44,1 \mathrm{mg} / 1$. Najwyższe wartości rozpuszczonego węgla organicznego zostały zaobserwowane w sezonie zimowym, zwłaszcza w próbkach śnieżnych. Natomiast średnie wartości RWO w porze suchej były wyższe od wartości uzyskanych w porze deszczowej [25]. Podobne wahania sezonowe stwierdzono również na terenie Brazylii [26].

\section{Metody oznaczania ogólnego węgla organicznego}

Obecnie istnieje kilka norm europejskich zawierających wytyczne dotyczące prawidłowego oznaczania zawartości węgla organicznego w różnych typach wód oraz w ściekach. Na ich podstawie dokonano szczegółowej klasyfikacji wszystkich oznaczalnych form węgla (Tab. 2) oraz graficznie przedstawiono ich podział (Rys. 1). Zasada pomiaru OWO i RWO opisana została w normie PN-EN 1484:1999.

Tabela 2. Terminy wykorzystywane w analizie związków węgla, na podstawie [30]

Table 2. The terms used in the analysis of carbon, based on [30]

\begin{tabular}{|c|c|c|}
\hline Nazwa & Skrót & Charakterystyka \\
\hline Ogólny węgiel & $\mathrm{OW}$ & $\begin{array}{l}\text { Sumaryczna zawartość węgla nieorganicznego, } \\
\text { węgla organicznego oraz węgla pierwiastkowego; } \\
\text { OW = OWN + OWO }\end{array}$ \\
\hline $\begin{array}{l}\text { Ogólny węgiel } \\
\text { nieorganiczny }\end{array}$ & OWN & \multirow{3}{*}{$\begin{array}{l}\text { Sumaryczna zawartość węgla nieorganicznego } \\
\text { występującego w postaci węglanu, wodorowę- } \\
\text { glanu oraz rozpuszczonego dwutlenku węgla; } \\
\text { OWN = OW - OWO } \\
\text { OWN = RWN + CWN }\end{array}$} \\
\hline $\begin{array}{l}\text { Rozpuszczony węgiel nie- } \\
\text { organiczny }\end{array}$ & RWN & \\
\hline $\begin{array}{l}\text { Zawieszony węgiel } \\
\text { nieorganiczny }\end{array}$ & ZWN & \\
\hline $\begin{array}{l}\text { Ogólny węgiel } \\
\text { organiczny }\end{array}$ & OWO & $\begin{array}{l}\text { Sumaryczna zawartość węgla organicznego pocho- } \\
\text { dzącego z materii rozpuszczonej bądź zawieszonej } \\
\text { w wodzie; } \\
\text { OWO = RWO + ZWO, } \\
\text { OW = NUWO + LWO }\end{array}$ \\
\hline
\end{tabular}


Tabela 2 cd. Terminy wykorzystywane w analizie związków węgla, na podstawie [30]

Table 2 cont. The terms used in the analysis of carbon, based on [30]

\begin{tabular}{|c|c|c|}
\hline Nazwa & Skrót & Charakterystyka \\
\hline $\begin{array}{l}\text { Rozpuszczony węgiel } \\
\text { organiczny }\end{array}$ & RWO & $\begin{array}{l}\text { Sumaryczna zawartość rozpuszczonych związ- } \\
\text { ków organicznych przechodzących przez } \\
\text { membranowy filtr o wielkości porów } 0,45 \mu \mathrm{m} ; \\
\text { RWO = UWO + NURWO, } \\
\text { RWO = OWO - ZWO }\end{array}$ \\
\hline $\begin{array}{l}\text { Zawieszony węgiel } \\
\text { organiczny }\end{array}$ & ZWO & $\begin{array}{l}\text { Zawieszone cząstki zatrzymane przez filtr } \\
\text { o wielkości porów } 0,2-10 \mu \mathrm{m} ; \\
\text { ZWO }=\mathrm{OWO}-\mathrm{RWO}\end{array}$ \\
\hline $\begin{array}{l}\text { Lotny węgiel organicz- } \\
\text { ny/Usuwalny węgiel orga- } \\
\text { niczny }\end{array}$ & $\begin{array}{l}\text { LWO/ } \\
\text { UWO }\end{array}$ & $\begin{array}{l}\text { Związki o niskiej masie cząsteczkowej; Węgiel } \\
\text { organiczny usuwalny przez wydmuchiwanie } \\
\text { (Wielu autorów używa zamiennie określeń LWO } \\
\text { i UWO) }\end{array}$ \\
\hline $\begin{array}{l}\text { Nieusuwalny węgiel orga- } \\
\text { niczny /Nielotny węgiel } \\
\text { organiczny }\end{array}$ & $\begin{array}{l}\text { NUWO/ } \\
\text { NLWO }\end{array}$ & \multirow{2}{*}{$\begin{array}{l}\text { Węgiel organiczny nieusuwany poprzez wydmu- } \\
\text { chiwanie; } \\
\text { NUWO = NURWO + ZWO }\end{array}$} \\
\hline $\begin{array}{l}\text { Nieusuwalny rozpuszczony } \\
\text { węgiel organiczny }\end{array}$ & NURWO & \\
\hline
\end{tabular}

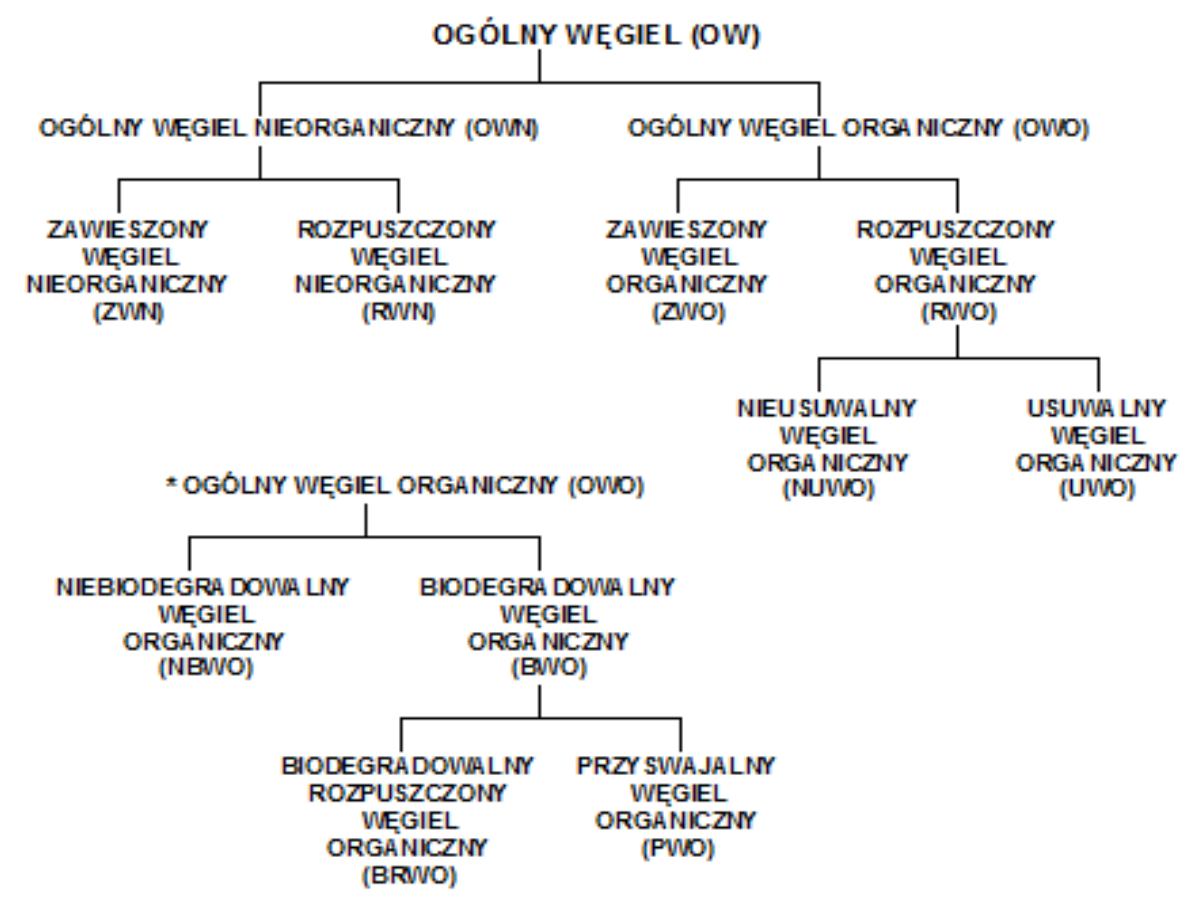

* Inny podział Ovo uwzględniający biodegradowalność związków organicznych

Rys. 1. Podział związków organicznych występujących w wodach naturalnych [Oprac. własne]

Fig. 1. Distribution of organic compounds present in natural waters [Own elaboration] 
W celu wyznaczenia OWO można posłużyć się kilkoma metodami, jednak przy wyborze odpowiedniej techniki należy wziąć pod uwagę następujące czynniki: rodzaj analizowanej próbki, czas trwania pomiaru, wpływ interferencji, precyzję i czułość metody, a także generowane koszty [1]. Obecnie na rynku znajduje się wiele urządzeń służących do pomiaru OWO, które różnią się między sobą sposobem utleniania obecnych w próbce związków organicznych i/lub detektorem. Do najczęściej wykorzystywanych metod mineralizacji zalicza się przeprowadzanie analizowanych próbek w stan gazowy. Tego typu przemiana może nastąpić podczas katalitycznego utlenienia niskotemperaturowego oraz utleniania wysokotemperaturowego [1,4].

Główne wady i zalety wymienionych metod mineralizacji zostały zestawione w tabeli 3 .

Tabela 3. Metody wykorzystywane do oznaczenia OWO, na podstawie [4]

Table 3. The methods used for the determination of TOC, based on [4]

\begin{tabular}{|c|c|c|}
\hline Metoda & Zalety & Wady \\
\hline $\begin{array}{c}\text { Utlenienie } \\
\text { promieniowaniem UV }\end{array}$ & $\begin{array}{l}\text { - niski koszt utrzymania, } \\
\text { - nie wymaga stosowania } \\
\text { odczynników chemicznych }\end{array}$ & $\begin{array}{l}\text { - niska dokładność dla warto- } \\
\text { ści poniżej } 5 \text { ppm, } \\
\text { - stosunkowo niski stopień } \\
\text { utleniania, } \\
\text { - wymagana duża objętości } \\
\text { próbki, } \\
\text { - długi czas analizy }\end{array}$ \\
\hline $\begin{array}{l}\text { Utlenienie } \\
\text { niskotemperaturowe } \\
\text { (promieniowanie UV } \\
\quad \text { + nadsiarczan) }\end{array}$ & $\begin{array}{l}\text { - niski koszt utrzymania, } \\
\text { - wysoka czułość, } \\
\text { - duża dokładność, } \\
\text { - wysoki odzysk } \mathrm{CO}_{2} \text { w wielu } \\
\text { zastosowaniach, } \\
\text { - duża szybkość utleniania }\end{array}$ & $\begin{array}{l}\text { - możliwość wystąpienia } \\
\text { interferencji pochodzących } \\
\text { od chlorków podczas detek- } \\
\text { cji } \mathrm{CO}_{2} \text { w atmosferze boga- } \\
\text { tej w tlen }\end{array}$ \\
\hline $\begin{array}{c}\text { Utlenianie } \\
\text { w podwyższonej } \\
\text { temperaturze } \\
\text { z wykorzystaniem } \\
\text { nadsiarczanu }\end{array}$ & $\begin{array}{l}\text { - niski koszt utrzymania, } \\
\text { - wysoka czułość, } \\
\text { - duża dokładność, } \\
\text { - wysoki odzysk } \mathrm{CO}_{2} \text { w wielu } \\
\text { zastosowaniach }\end{array}$ & $\begin{array}{l}\text { - długi czas utleniania, } \\
\text { - w przypadku wysokiego } \\
\text { poziomu TOC następuje } \\
\text { nieilościowy odzysk }\end{array}$ \\
\hline $\begin{array}{c}\text { Utlenianie } \\
\text { wysokotemperaturowe }\end{array}$ & $\begin{array}{l}\text { - krótki czas analizy, } \\
\text { - możliwość utlenienia sub- } \\
\text { stancji stałych występują- } \\
\text { cych w analizowanej próbce } \\
\text { wody, } \\
\text { - względnie niski poziom } \\
\text { interferencji }\end{array}$ & $\begin{array}{l}\text { - wysoki koszt utrzymania, } \\
\text { - mała czułość, } \\
\text { - możliwość wykonania ana- } \\
\text { lizy jedynie przy małej za- } \\
\text { wartości soli, } \\
\text { - możliwość straty } \mathrm{CO}_{2} \text { wy- } \\
\text { stępującego w strumieniu } \\
\text { kondensującej pary wodnej, } \\
\text { - problem z odzyskiem części } \\
\text { związków aromatycznych, } \\
\text { - zatrucia katalizatorów }\end{array}$ \\
\hline
\end{tabular}


Dostępne na rynku analizatory OWO posiadają podobną (zgodną z normą europejską) zasadę działania, ale różnią się sposobem wprowadzania próbki, metodą utleniania, detekcją oraz rejestracją wyników [30].

Dotychczas przeprowadzono wiele badań, których celem było porównanie skuteczności metod stosowanych do pomiaru OWO w próbkach ciekłych $[1,4]$. Stwierdzono, że najbardziej odpowiednią metodą jest utlenienie z wykorzystaniem nadsiarczanu oraz metoda utleniania dodatkowo wspomagana promieniowaniem UV wówczas gdy analizowana próbka zawiera OWO w ilości większej niż $1 \mathrm{mg} / \mathrm{l}$. Z kolei dla wód morskich najlepsze rezultaty uzyskuje się stosując wysokotemperaturowe utlenianie. Dzięki zastosowaniu tego sposobu możliwe jest oznaczenie znacznie większej ilości węgla organicznego niż w przypadku metody wykorzystującej nadsiarczan [4].

\section{Biodegradowalna materia organiczna - metody oznaczania}

Materię organiczną występującą w wodzie można podzielić na dwie podstawowe frakcje: biodegradowalną oraz referencyjną (odporną na biodegradację) $[31,32]$. W skład biodegradowalnej materii organicznej (BMO) wchodzą m.in.: biodegradowalny rozpuszczony węgiel organiczny (BRWO) oraz przyswajalny węgiel organiczny (PWO). Dominującą frakcją jest BRWO, który osiąga znacznie wyższe wartości w analizowanych próbkach niż PWO. Wymienione powyżej frakcje mogą być metabolizowane i wbudowywane w struktury komórki bakterii heterotroficznych. Podatność materii organicznej na biodegradację zależy głównie od składu chemicznego oraz masy cząsteczkowej danej substancji, a także od enzymatycznej aktywności bakterii [33]. Pomiar BMO jest rutynowo stosowany w analizach laboratoryjnych jako jeden z głównych parametrów jakości wody pitnej, decydujący o jej biologicznej aktywności.

Woda wprowadzana do systemu dystrybucji musi być stabilna biologicznie, gdyż w przeciwnym wypadku istnieje niebezpieczeństwo wtórnego rozwoju mikroorganizmów, które następnie będą gromadzić się na powierzchniach rurociągów, tworząc tzw. biofilm. Ich obecność odpowiedzialna jest również za intensyfikację procesu korozji części metalowych systemu wodociągowego, zwiększenie zapotrzebowania na dezynfektant oraz znacznie podnosi koszty eksploatacji systemu dystrybucji wody. Ponadto brak stabilności wody może doprowadzić do wtórnego jej zanieczyszczenia oraz naruszenia norm dotyczących jakości wody przeznaczonej do spożycia [21, 34, 35]. Duży udział substancji organicznych w wodzie jest również odpowiedzialny za niepożąany smak i zapach wody $[10,33]$.

Obecność w wodzie BRWO i PWO stwarza idealne warunki do rozwoju mikroorganizmów heterotroficznych, w tym również organizmów patogennych i chorobotwórczych. Przyjmuje się, że wartość PWO powinna wynosić w wodzie niechlorowanej $0,01 \mathrm{mg} / \mathrm{l}$, według innego źródła $0,03 \mathrm{mg} / \mathrm{l}$. Natomiast w wodzie chlorowanej, rozwój heterotroficznych bakterii zostaje zahamowany 
przy stężeniu PWO wynoszącym od 0,05 do $0,1 \mathrm{mg} / \mathrm{l}$. Z kolei w przypadku BRWO wartości powinny mieścić się w zakresie od 0,15 do $0,3 \mathrm{mg} / \mathrm{l}$. Gdy wartości PWO i BRWO w wodzie dezynfekowanej wynoszą odpowiednio więcej niż 0,15 i 0,5 mg/l wówczas konieczne jest zredukowanie ilości obu frakcji [35].

Nie wszystkie związki organiczne obecne $\mathrm{w}$ wodzie podlegają biodegradacji, w rzeczywistości tylko frakcja o małej masie cząsteczkowej może być przyswajana przez bakterie. Metody oznaczania biodegradowalnej materii organicznej obejmują zarówno wyznaczenie całego BRWO jak również frakcji PWO. Do oznaczenia przyswajalnego węgla organicznego najczęściej stosuje się metodę van der Kooija oraz Wernera, natomiast do pomiaru BRWO metodę Servaisa i Joreta [31, 36].

Główną wadą tych metod jest zbyt długi czas inkubacji, który może stanowić utrudnienie w przypadku wykonywania częstych analiz [36, 37]. Ze względu na ograniczenia czasowe opracowano znacznie szybszy sposób pomiaru BRWO, wykorzystując do tego celu skolonizowany przez autochtoniczne bakterie bioreaktor. Koncepcja bioreaktora w kolejnych latach została udoskonalona przez Kaplana i Newbolda [32]. Następnie do oznaczeń biodegradowalnego węgla organicznego wykorzystano bioreaktory z immobilizowanymi komórkami mikroorganizmów w wyniku czego znacznie skrócono czas potrzebny do kolonizacji wypełnienia [37].

\section{Wnioski}

- Naturalna materia organiczna (NOM) jest ogólnym terminem określającym wszystkie związki organiczne występujące w wodach naturalnych, od wód deszczowych, rzecznych, jeziornych, podziemnych do wód morskich.

- Ogólny węgiel organiczny w wodach naturalnych może przyjmować wartości od $1 \mathrm{mg} / \mathrm{l}$ do ponad $100 \mathrm{mg} / \mathrm{l} \mathrm{w}$ zależności od typu analizowanej wody (wraz ze wzrostem stopnia zanieczyszczenia wody zwiększa się stężenie OWO).

- W wodach naturalnych węgiel organiczny może występować w dwóch podstawowych formach - rozpuszczonej (RWO) i zawieszonej (ZWO). Łączna suma tych obu parametrów stanowi całkowitą zawartość OWO. Ponadto materia organiczna występująca w wodzie możne zostać podzielona na dwie frakcje: biodegradowalną oraz referencyjną. Wymienione powyżej frakcje mogą być metabolizowane $\mathrm{i}$ wbudowywane w materiał komórkowy bakterii heterotroficznych.

- Wzrost zawartości ogólnego węgla organicznego w wodach, które ujmowane są w celu zaopatrywania ludności w wodę przeznaczoną do picia niejednokrotnie wpływa na znaczne zwiększenie kosztów jej uzdatniania. Obecność substancji organicznych, a przede wszystkim substancji humusowych przyczynia się do pogorszenia właściwości organoleptycznych wody m.in. są one odpowiedzialne za występowanie specyficznego smaku i zapachu, a także za ponadnormatywną barwę. 
- Pomiar BMO jest stosowany jako jeden z głównych parametrów charakteryzujących jakość wody użytkowej, decydujący o jej biologicznej aktywności. Obecność BRWO i PWO w wodzie wprowadzanej do systemu dystrybucji stwarza idealne warunki do rozwoju mikroorganizmów heterotroficznych, w tym również organizmów patogennych i chorobotwórczych.

\section{Literatura}

[1] Bożym M., Sławińska I., Halska - Bonkosz M.: Oznaczanie OWO w wodzie podziemnej, Wodociągi - Kanalizacja, nr 11, 2010, s. 52 - 55.

[2] Gomółka E., Szaynok A.: Chemia wody i powietrza, Oficyna Wydawnicza Politechniki Wrocławskiej, Wrocław 1997.

[3] Juszczyk D., Bebek M., Mitko K.: Oznaczenie ogólnego węgla organicznego (OWO) w wodzie i ściekach metodą utleniania chemicznego w fazie ciekłej, Gaz, Woda i Technika Sanitarna, nr 10, 2004, s. 355 - 358.

[4] Raczyk - Stanisławiak U., Świetlik J., Kasprzyk B., Nawrocki J.: The efficiency of different oxidation methods in total organic carbon analysis, Chemia Analityczna, 48 (2), 2003, s. $243-254$.

[5] Visco G., Campanella L., Nobili V.: Organic carbons and TOC in waters: an overview of the international norm for its measurements, ScienceDirect, Micrrochemical Journal 79, 2005, pp. $185-191$.

[6] Rozporządzenie Ministra Ochrony Środowiska z dnia 27 listopada 2002r. w sprawie wymagań, jakim powinny odpowiadać wody powierzchniowe wykorzystywane do zaopatrzenia ludności w wodę przeznaczoną do spożycia.

[7] Rozporządzenie Ministra Środowiska z dnia 18 listopada 2014 r. w sprawie warunków, jakie należy spełnić przy wprowadzaniu ścieków do wód lub do ziemi, oraz w sprawie substancji szczególnie szkodliwych dla środowiska wodnego.

[8] Rozporządzenie Ministra Zdrowia z dnia 13 listopada 2015 r. w sprawie jakości wody przeznaczonej do spożycia przez ludzi.

[9] Mołczan M., Szlachta M., Karpińska A., Biłyk A.: Zastosowanie absorbancji właściwej w nadfiolecie (SUVA) w ocenie jakości wody, Ochrona Środowiska, nr 4, 2006, s. 12 - 16.

[10] Krupińska I.: Problemy związane $\mathrm{z}$ występowaniem substancji humusowych w wodach podziemnych, Inżynieria Środowiska, Zeszyty Naukowe 148, nr 28, 2012 , s. $55-68$.

[11] Ignatowicz K.: Graveyard - Point Source Pollution of Natural Water by Pesticides, Ecological Chemistry and Engineering. Vol. 18, nr 2, 2011, s. $191-200$.

[12] Kiryluk A., Leszczyński J., Łukowski A., Miłaszewski R., Piekutin J., Siemieniuk A., Skorbiłowicz E., Skorbiłowicz M., Szczykowska J., Wiater J., Żebranowicz E.: Źródło zanieczyszczeń wód powierzchniowych i wybrane metody ich oczyszczania, Budownictwo i Inżynieria Środowiska, nr 5, 2014, s. 49 - 57.

[13] Ouyang Y.: Simulating dynamic load of naturally occurring TOC from watershed into a river, Water Research 37, 2003, pp. 823 - 832.

[14] Michael - Kordatou I., Michael C., Duan X., He X., Dioysiou D.D., Mills M. A., Fatta - Kassinos D.: Dissolved effluent organic matter: Characteristics and potential implications in wastewater, Water research 77, 2015, pp. 213 - 248. 
[15] Pisarek I., Głowacki M.: Quality of groundwater and aquatic humic substances from main reservoir of ground water No. 333, Journal of Ecological Engineering, Volume 16, Issue 5, 2015, pp. 46 - 53.

[16] Hytteborn J., Temnerud J., Alexander R. B., Boyer E. W., Futter M. N., Fröberg M., Dahné J., Bishop K. H.: Patterns and predictability in the intra-annual organic carbon variability across the boreal and hemiboreal landscape, Science of the Total Environment 520, 2015, pp. 260 - 269.

[17] Mattsson T., Kortelainen P., Lepistö A., Räike A.: Organic and minerogenic acidity in Finnish rivers in relation to land use and deposition, Science of the Total Environment 383, 2007, pp. $183-192$.

[18] Mora A., Laraque A., Moreira - Turcq P., Alfonso J. A.: Temporal variation and fluxes of dissolved and particulate organic carbon in the Apure, Caura and Orinoco rivers, Venezuela, Journal of South American Earth Sciences 54, 2014, pp. 47 - 56.

[19] Rodríguez - Murillo J. C., Zobrist J., Filella M.: Temporal trends in organic carbon content in the main Swiss rivers, 1974 - 2010, Science of the Total Environment 502, 2015 , pp. $206-217$.

[20]Xiao Y., Räike A., Hartikainen H., Vähätalo A.: Iron as a source of color in river waters, Science of the Total Environment 536, 2015, pp. $914-923$.

[21] Kutser T., Verpoorter C., Paavel B., Tranvik L. J.: Estimating lake carbon fractions from remote sensing data, Remote Sensing of Environment 157, 2015, pp. $138-146$.

[22] Kiryluk A.: Stężenie ogólnego węgla organicznego w wodzie ekosystemów pobagiennych różnie użytkowanych, Woda - Środowisko - Obszary Wiejskie, t. 6 z. 1(16), 2006, s. 173 - 181.

[23] Poté J., Mavingui P., Navarro E., Rosselli W., Wildi W., Simonet P., Vogel T. M.: Extracellular plant DNA in Geneva groundwater and traditional artesian drinking water fountains, Chemosphere 75, 2009, pp. 498 - 504.

[24] Piekutin J.: Zanieczyszczenia wody gruntowej związkami organicznymi, Inżynieria Ekologiczna nr 26, 2011, s. 95 - 102.

[25] Pan Y., Wang Y., Xin J., Tang G., Song T., Wang Y., Li X., Wu F.: Study on dissolved organic carbon in precipitation in Northern China, Atmospheric Environment 44, 2010, pp. 2350 - 2357.

[26] Coes A. L., Paretti N. V., Foreman W. T., Iverson J. L., Alvarez D. A.: Sampling trace organic compounds in water: A comparison of a continuous active sampler to continuous passive and discrete sampling methods, Science of the Total Environment 473 - 474, 2014, pp. 731 - 741.

[27] Maciejewska A., Pempkowiak J.: DOC and POC in the water column of the southern Baltic. Part I. Evaluation of factors influencing sources, distribution and concentration dynamics of organic matter, Oceanologia, 56 (3), 2014, pp. 523 - 548.

[28]Zabiegała B.: Oznaczenie zawartości węgla całkowitego, całkowitego węgla organicznego oraz węgla nieorganicznego w próbkach środowiskowych z kulometrycznym oznaczeniem końcowym, Chemia analityczna, Wydział Chemiczny Politechnika Gdańska, 2002.

[29] XI Min, LU Xianguo, LI Yue, KONG Fanlong: Distribution characteristics of dissolved organic carbon in annular wetland soil-water solutions through soil profiles in the Sanjiang Plain, Northeast China, Journal of Environmental Sciences 19, 2007, pp. $1074-1078$. 
[30] Bisutti I., Hilke I., Raessler M.: Determination of total organic carbon - an overview of current methods, Trends in Analytical Chemistry, Vol. 23, No. 10 - 11, 2004, pp. $716-726$.

[31] Rosińska A., Rokocz K.: Rola biodegradowalnej materii organicznej w procesie dezynfekcji wody, Inżynieria i Ochrona Środowiska, t. 16, nr 4, 2013, s. 511 -521.

[32] Kaplan L. A., Newbold J. D.: Measurement of streamwater biodegradable dissolved organic carbon with a plug - flow bioreactor, Wat.Res, Vol. 29, No. 12, 1995, pp. 2696 - 2706.

[33] Polańska M., Huysman K., Keer Ch.: Investigation of assimilable organic carbon (AOC) in Flemish drinking water, Water Research 39, 2005, pp. 2259 - 2266.

[34] Świderska - Bróż M.: Skutki braku stabilności biologicznej wody wodociągowej, Ochrona Środowiska, nr 4, 2003, s. 7 - 12.

[35] Świderska - Bróż M.: Czynniki współdecydujące o potencjale powstawania i rozwoju biofilmu w systemach dystrybucji wody, Ochrona Środowiska, nr 3, Vol. 32, 2010, s. 7 - 13.

[36] Biłozor S., Danielak K.: Ocena podatności związków organicznych w wodzie na biodegradacje, Ochrona Środowiska nr 4 (67), 1997, s. 55 - 58.

[37] Khan E., Babcock R. W., Jongskul S., Devadason F. A., Tuprakay S.: Determination of biodegradable dissolved organic carbon using entrapped mixed microbial cells, Water Research 37, 2003, pp 4981-4991.

\section{ORGANIC MATTER IN NATURAL WATER - FORMS AND METHOD FOR DETERMINING}

\section{S u m m a r y}

Concentration of organic matter is an important parameter for determining the degree of pollution of natural water. The only well-defined indicator that represents the sum of all organic contaminants is the total organic carbon (TOC). The article shows the methods used to measure TOC and the form of organic matter presence in different types of waters. The content of total organic carbon in natural waters is varied and depends on the following factors: the type and size of the test water tank, geographic location, temperature, salinity, $\mathrm{pH}$, microbiological activity and land cover. The increase of total organic carbon in drinking water considerably increases the cost of its treatment. The presence of organic matter in particular humic substances contributes to the deterioration of the organoleptic properties of water, among others, they are responsible for the occurrence of a specific taste and aroma and for the enhanced color.

Keywords: total organic carbon (TOC), particulate organic carbon (POC), dissolved organic carbon (DOC), biodegradable organic carbon (BOC)

Przestano do redakcji: 11.04.2016 r.

Przyjęto do druku: $1.06 .2016 r$.

DOI: $10.7862 / \mathrm{rb} .2016 .126$ 